\title{
Alasan Pembuatasan Dan Perubahan Ketentuan Terkait Modal Dalam Perseroan Terbatas
}

\author{
Eka Purnamasari", Miftah Anshori ${ }^{* *}$, Gunarto*** \\ * Mahasiswa Program Magister (S2) Kenotariatan Fakultas Hukum UNISSULA, Semarang email : e-mail : \\ eqha.purnamasari@yahoo.co.id \\ ** Mahasiswa Program Magister (S2) Ilmu Hukum, Fakultas Hukum UNISSULA, Semarang, e-mail: \\ mifta5129@gmail.com \\ *** Dosen Fakultas Hukum UNISSULA
}

Abstrak

Modal merupakan faktor yang sangat penting, sebagai salah satu sarana untuk meraih keuntungan dalam kegiatan usaha, juga bagi eksitensi kelangsungan kehidupan maupun pengembangan perseroan terbatas sebagai organisasi ekonomi. Adapun Struktur modal seperti yang ditegaskan dalam Penjelasan Pasal 41 ayat (1) UUPT 2007, bahwa yang dimaksud dengan modal perseroan adalah modal dasar, ditempatkan, modal disetor. Dalam Pasal 32 ayat (1) UUPT 2007 terdapat pengaturan mengenai batas mininal dari modal dasar perseroan yaitu paling sedikit Rp 50.000.000,00 (lima puluh juta rupiah) kurang dari jumlah tersebut tidak diperbolehkan. Untuk modal ditempatkan juga ada batas minimal yang dicantumkan dalam Pasal 33 ayat (1) UUPT 2007, yaitu paling sedikit 25\% (dua puluh lima persen) dari modal dasar, harus ditempatkan. Kemudian untuk modal disetor berdasarkan Pasal 33 ayat (1) UUPT 2007 dihubungkan dengan ketentuan Pasal 33 ayat (3) UUPT 2007 dan penjelasannya harus disetor penuh, maksudnya adalah jika modal ditempatkan $50 \%$ dari modal dasar, maka modal yang harus disetor penuh 50\% dan tidak dapat diangsur. Tetapi, pada Peraturan Pemerintah Nomor 29 Tahun 2016 tentang Perubahan Modal Dasar Perseroan Terbatas ditentukan lain terkait modal dasar Perseroan Terbatas, yaitu modal dasar tersebut dikembalikan ke kesepakatan Para pendiri Perseroan Terbatas. Dari sekilas penjelasan diatas kita dapat melihat bahwa apabila kita ingin mendirikan sebuah Perseroan Terbatas ada pengaturan yang terkait mengenai batas minimal dari modal dalam peseroan terbatas, masalahnya adalah apakah alasan pembuatan dan perubahan ketentuan tentang modal Perseroan Terbatas?

Kata Kunci : Modal, Perseroan Terbatas, Pengaturan.

Abstract

Capital is a very important factor, because one means to gain profit in business activities, also for the survival and development of a limited liability company as an economic organization. Capital structure as referred to in Elucidation of Article 41 paragraph (1) law number 49 of 2007 on limited liability company, company capital is the authorized capital, issued capital and paid up capital. In Article 32 Paragraph (1) of the Limited Liability Company Act of 2007 there is a regulation concerning the minimum limit of authorized capital of a company of at least Rp $50,000,000.00$ (fifty million rupiah), less than the amount that is not permitted. For the issued capital there is also a minimum limit specified in Article 33 paragraph (1) UUPT 2007 which is at least $25 \%$ (twenty five percent) of the authorized capital. Furthermore, the paid up capital under Article 33 paragraph (1) of the Limited Liability Company Act of 2007 relates to the provisions of Article 33 paragraph (3) of the Limited Liability Company Law in 2007 and the explanation shall be paid, that is, if the capital is placed $50 \%$ of the authorized capital, must be paid in full $50 \%$ and can not be paid in installments. However, the government regulation number 29 of 2016 on changes in the authorized capital of a limited liability company is determined in relation to the authorized capital of a limited liability company, namely the athorized capital is returned to the agreement of the founders of the limited liability company. From the description above we can see that if we want to establish a Limited Liability Company there is a related regulation concerning the minimum limit of capital in a limited liability company, the problem is the reason why arrangements are made and needed in the Limited Liability Company?

Keyword : Capital, Limited Liability company, arrangements.

\section{PENDAHULUAN}

Perseroan Terbatas merupakan salah satu bentuk usaha yang mempunyai peranan sangat penting dalam perekonomian, selain itu Perseroan Terbatas juga merupakan bentuk kegiatan ekonomi yang sangat disukai saat ini, karena pertanggung- jawabannya yang hanya bersifat terbatas pada saham yang dimilikinya dan Perseroan Terbatas juga memberikan kemudahan bagi pemilik (pemegang saham) untuk mengalihkan kepada setiap orang dengan menjual seluruh saham yang dimilikinya pada perseroan tersebut. 
Kata "perseroan" menujuk pada modalnya yang terdiri atas sero (saham) sedangkan kata "terbatas" menunjuk pada pertanggungjawaban pemegang saham yang tidak melebihi nilai nominal saham yang diambil bagian dan yang dimilikinya. Menurut Pasal 1 Undang-undang Nomor 40 Tahun 2007 Tentang Perseroan Terbatas (untuk selanjutnya disebut UUPT 2007) disebutkan bahwa : "Peseroan Terbatas adalah badan hukum yang merupakan persekutuan modal, didirikan berdasarkan perjanjian, melakukan kegiatan usaha dengan modal dasar yang seluruhnya terbagi dalam saham dan memenuhi pesyaratan yang ditetapkan dalam Undang-undang ini serta peraturan pelaksanaannya."

Perseroan terbatas adalah badan hukum yang dimana keberadaan status badan hukumnya baru peroleh setelah ia memperoleh pengesahan dari pejabat yang berwenang memberikan hak-hak, kewajiban dan harta kekayaan sendiri bagi badan hukum tersebut, terlepas dari hak-hak, kewajiban dan harta kekayaan para pendiri, baik itu pemegang saham maupun pengurusnya.

Badan hukum merupakan pendukung hak dan kewajiban seperti manusia pribadi, sebagai gabungan hak dan kewajiban maka badan hukum mempunyai kekayaan sendiri yang terpisah dari kekayaan pengurus walaupun pendirinya. Apabila kekayaannya tidak mencukupi untuk memetupi kewajiban atau untuk membayar hutang-hutangnya maka tidak dapat mengambil dari kekayaan pengurus atau pendirinya. Harta kekayaan perseroan dapat terwujud dalam berbagai bentuk kebendaan, baik yang berupa benda bergerak maupun benda yang tidak bergerak, serta yang berwujud maupun yang tidak berwujud (hak-hak), sepanjang perseroan memenuhi syarat sebagai subjek hukum dari pemilik kebendaan tersebut.

Pada perseroan terbatas juga terdapat pemegang saham sebagai pemasok modal yang tanggung jawabnya tidak melebihi dari nilai saham yang diambilnya (modal yang disetor) dan harus ada pengurus yang terorganisir guna mewakili perseroan dalam menjalankan aktivitasnya dalam lalu lintas hukum, baik diluar maupun didalam Pengadilan dan tidak bertanggung jawab secara pribadi terhadap perkiraan-perkiraan yang dibuat oleh perseroan terbatas. $^{1}$

Modal merupakan faktor yang sangat penting artinya, bukan saja sebagai salah satu sarana untuk meraih keuntungan dalam kegiatan usaah perseroan terbatas, namun juga sangat penting artinya bagi eksitensi, kelangsungan kehidupan maupun

\footnotetext{
${ }^{1}$ Agus Budiarto, Kedudukan Hukum dan Tanggungjawab Pendiri Perseroan Terbatas, Ghalia Indonesia, Bogor, 2009, h. 19.
}

pengembangan perseroan terbatas sebagai organisasi ekonomi. Bagaimanapun modal adalah sarana untuk meraih laba yang sebesar-besarnya, sedangkan laba adalah tujuan dari kegiatan usaha perseroan yang nantinya dibagi-bagikan kepada pemegang saham dalam bentuk deviden. ${ }^{2}$

Struktur modal perseroan terdiri atas modal dasar (statutair kapital, nominal/authorized capita), modal ditempatkan (geplaats kapital, issued/subscribe capital), dan modal disetor (gestrot kapital, paid-up capital) $)^{3}$. Seperti yang ditegaskan dalam Penjelasan Pasal 41 ayat (1) UUPT 2007, bahwa yang dimaksud dengan modal perseroan adalah modal dasar, modal ditempatkan, modal disetor.

Dalam Pasal 32 ayat (1) UUPT 2007 terdapat pengaturan mengenai batas mininal dari modal dasar perseroan, kurang atau lebih dari jumlah tersebut tidak diperbolehkan. Untuk modal ditempatkan juga ada batas minimal yang dicantumkan dalam Pasal 33 ayat (1) UUPT 2007. yaitu paling sedikit $25 \%$ (dua puluh lima persen) dari modal dasar, harus ditempatkan. Kemudian untuk modal disetor berdasarkan Pasal 33 ayat (1) UUPT 2007 dihubungkan dengan ketentuan Pasal 33 ayat (3) UUPT 2007 dan penjelasannya harus disetor penuh, maksudnya adalah jika modal ditempatkan $50 \%$ dari modal dasar, maka modal yang harus disetor penuh $50 \%$ dan tidak dapat diangsur.

Dalam rangka memenuhi kebutuhan dan kepastian dalam dunia usaha serta mendorong kemudahan berusaha, pemerintah kembali mengeluarkan peraturan baru, yang tidak lain dan tidak bukan adalah Peraturan Pemerintah Nomor 29 Tahun 2016 tentang Perubahan Modal Dasar Perseroan Terbatas, peraturan ini mengatur beberapa aspek penting dalam Perseroan Terbatas antara lain besaran jumlah modal dasar dan batas waktu penyetoran modal, peraturan ini secara khusus mengatur pelaksanaan Pasal 32 ayat (3) UUPT.

Dari sekilas penjelasan diatas kita dapat melihat bahwa apabila kita ingin mendirikan sebuah Perseroan Terbatas ada pengaturan yang terkait mengenai batas minimal dari modal dalam peseroan terbatas, masalahnya adalah apakah alasan pembuatan dan perubahan ketentuan tentang modal Perseroan Terbatas?

\section{Pembahasan}

Pengaturan Modal Perseroan Terbatas dalam

\footnotetext{
${ }^{2}$ Agus Budiarto, op.cit, h. 51.

${ }^{3}$ Walter Woon, Company Law, Longman Singapore Publisher Pte Ltd, Singapore, h. 81
} 


\section{Undang-Undang Nomor 1 tahun 1995 tentang Perseroan Terbatas}

Rincian pengaturan modal Perseroan Terbatas pada UUPT 1995, adalah sebagai berikut:

\section{Modal dasar}

Mengenai batas minimal modal dasar (authorized minimun), adalah jumlah yang paling rendah yang dibenarkan undang-undang untuk dicantumakan dalam Anggaran Dasar, kurang dari jumlah yang ditentukan dari jumlah batas minimal tersebut tidak dibenarkan. Berdasarkan Pasal 25 ayat (1) UUPT 1995, modal dasar Perseroan Terbatas yang dibenarkan adalah paling sedikit $\mathrm{Rp}$ 20.000.000,00 (dua puluh juta rupiah).

\section{Modal ditempatkan}

Berdasarkan ketentuan Pasal 26 ayat (1) UUPT 1995 jumlah modal dasar yang harus ditempatkan adalah paling sedikit $25 \%$ (dua puluh lima persen) dari modal dasar harus ditempatkan.

\section{Modal disetor}

Mengenai posisi dari modal disetor, perlu diperhatikan ketentuan Pasal 26 ayat (2) UUPT 1995, yang berbunyi : "Setiap penempatan modal sebagaimana dimaksud dalam ayat (1) harus telah disetor paling sedikit 50\% (lima puluh persen) dari nilai nominal setiap saham yang dikeluarkan". Berdasarkan ketentuan ini, maka paling sedikit 50\% (lima puluh persen) dari modal dasar harus telah disetor pada saat pendirian Peseroan Terbatas.

\section{Pengaturan Modal Perseroan Terbatas dalam Undang-Undang Nomor 40 tahun 2007 tentang Perseroan Terbatas.}

Perseroan terbatas terdiri dua kata, yaitu perseroan dan terbatas. Perseroan menunjuk kepada modal perseroan terbatas yang terdiri dari sero-sero atau saham-saham, sedangkan terbatas menunjuk kepada tanggungjawab pemegang saham yang luasnya hanya terbatas pada nilai nominal saham yang dimilikinya. ${ }^{4}$ UUPT tidak memberikan arti atau definisi tentang modal. Undang-undang tersebut hanya menyebutkan bahwa modal dasar Perseroan Terbatas terdiri atas seluruh nilai saham. ${ }^{5}$ UUPT sendiri tidak menutup kemungkinan peraturan perundang-undangan di bidang pasar modal mengatur modal Perseroan Terbatas terdiri atas

\footnotetext{
4 Ridwan Khairandy, Perseroan Terbatas Doktrin, Peraturan Perundang-undangan, dan Yurispudensi, Total Media, Yogyakarta, 2009, h. 1.

${ }^{5}$ Binoto Nadapdap, Hukum Perseroan Terbatas (Berdasrkan Undang-Undang No. 40 Tahun 2007), Jala Permata Aksara, Jakarta, 2016, h. 61
}

saham tanpa nilai nominal. ${ }^{6}$ Dalam UUPT 2007 menyebutkan modal, adapun jenis-jenis modal yang ada dalam perseroan terbatas, adalah:

1. Modal dasar

Modal dasar (statutair kapital, nominal/authorized capital) adalah seluruh nilai nominal saham perseroan yang disebut dalam Anggaran Dasar. ${ }^{7}$ Dan saham yang dimaksud dapat dikeluarkan atas nama atau atas tunjuk (aan toonder). Hal itu ditegaskan dalam Pasal 31 ayat (1) UUPT, bahwa modal dasr Perseroan Terbatas terdiri dari seluruh nilai nomial saham. Perkataan modal (kapital, capital) jika dihubungkan dengan Perseroan Terbatas mengandung pengertian, sesuatu yang diperoleh Perseroan Terbatas dalam bentuk uang melalui penerbitan saham (Issued of shares). Uang itulah yang kemudian digunakan Perseroan Terbatas untuk melancarkan kegiatan usaha dan bisnis yang ditentukan dalam Anggaran Dasar. Modal dasar Perseroan pada prinsipnya merupakan total dari jumlah saham yang dietrbitkan oleh Perseroan Terbatas. Angaran Dasar sendiri yang menentukan berapa banyak jumlah saham yang akan dijadikan modal dasar. Jumlah yang ditentukan dalam Anggaran Dasar, merupakan "nilai nominal yang murni".

Dengan demikian, setiap lembar saham mempunyai "nilai nominal" yang akan menjadi jumlah nilai nominal modal dasar Perseroan terbatas, yang sama nilainya dengan nilai nominal seluruh saham. Pasal 331 ayat (2) UUPT 2007 memberi kemungkinan menetapkan "saham tanpa nilai nominal". Kemungkinan itu bisa terjadi apabila peraturan perundang-undangan di bidang Pasar Modal mengatur modal Perseroan terbatas terdiri atas saham tanpa nilai nominal.

Mengenai batas minimal modal dasar (authorized minimun), adalah jumlah yang paling rendah yang dibenarkan undang-undang untuk dicantumakan dalam Anggaran Dasar, kurang dari jumlah yang ditentukan dari jumlah batas minimal tersebut tidak dibenarkan. Berdasarkan Pasal 32 ayat (1) UUPT 2007, modal dasar Peseroan yang dibenarkan adalah paling sedikit Rp 50.000.000,00 (lima puluh juta rupiah).

Pada Pasal 32 ayat (2) membuka kemungkinan menetapkan jumlah minimal modal dasar Perseroan Terbatas yang lebih besar dari Rp $50.000 .000,00$ (lima puluh juta rupiah). Kemungkinan itu terbuka bagi Perseroan Terbatas yang melakukan kegiatan usaha tertentu dengan

\footnotetext{
${ }^{6}$ Lihat Pasal 31 ayat (2) Undang-Undang Nomor 40 tahun 2007.

${ }^{7}$ M. Yahya Harahap, Hukum Perseroan Terbatas, Sinar Grafika, Jakarta, 2011, h. 233.
} 
syarat hal itu ditentukan dalam undang-undang yang mengatur kegiatan usaha tertentu itu. Menurut penjelasan Pasal 32 ayat (2) UUPT 2007, kegiatan usaha tertentu tersebut antara lain adalah: usaha perbankan, asuransi, atau freight/forwording.

Sesuai dengan ketentuan Pasal 21 ayat (2) huruf d UUPT 2007, perubahan Anggaran Dasar mengenai besarnya modal dasar, termasuk perubaahn Anggaran Dasar tertentu yang memerlukan persetujuan dari Menteri. Modal dasar yang ditetapkan dalam Anggaran Dasar boleh diperbesar atau diperkecil jumlahnya, asalkan perubaahn tersebut harus sesuai dengan tata cara yang ditentukan dalam Pasal 21 dan Pasal 22 UUPT 2007, serta harus dimintai persetujuan dari Menteri seperti yang sudah dijelaskan pada pembahasan perubahan Anggaran Dasar.

\section{Modal ditempatkan}

Modal ditempatkan (geplaats kapital, issued/subscribe capital) adalah saham yang telah diambil dan sebenarnya telah terjual, baik kepada pendiri maupun pemegang saham perseroan terbatas. Para pendiri atau pemegang saham yang telah menyanggupi untuk mengambil bagian sebesar atau sejumlah tertentu dari saham perseroan dan karena itu, dia mempunyai kewajiban untuk membayar atau melakukan penyetoran kepada perseroan. ${ }^{8}$ Berdasarkan ketentuan Pasal 33 ayat (1) UUPT 2007 jumlah modal dasar yang harus ditempatkan adalah paling sedikit $25 \%$ (dua puluh lima persen) dari modal dasar harus ditempatkan.

\section{Modal disetor}

Modal disetor (gestrot kapital, paid-up capital) adalah bagian dari modal yang dietmpatkan atau diambil bagian oleh para pendiri (sebelum peseroan berbadan hukum) atau pemegang saham (setelah perseroan berbadan hukum) yang disetor oleh pendiri atau pemegang saham kepada perseroan terbatas. Jadi, modal yang disetor adalah saham yang telah dibayar penuh kepada perseroan yang menjadi penyertaan atau penyetoran modal riil yang telah dilakukan oleh pendiri maupun para pemegang saham.

Mengenai posisi dari modal disetor, perlu diperhatikan ketentuan Pasal 33 ayat (1) UUPT 2007, yang berbunyi : "Paling sedikit 25\% (dua pulu lima persen dari modal dasar sebagaimana dimaksud dalam Pasal 32 haru ditempatkan dan disetor penuh". Berdasarkan ketentuan ini, maka paling sedikit 25\% (dua puluh lima persen) dari modal dasar : harus telah ditempatkan; dan juga harus

\footnotetext{
8 Jamin Ginting, Hukum Perseroan Terbatas (Undang-undang Nomor 40 Tahun 2007), Citra aditya Bakti, Bandung, 2007, h. 56.
}

telah disetor pada saat pendirian Peseroan Terbatas.

Sekiranya modal ditempatkan diambil para pendiri 50\% (lima puluh persen) atau 70\% (tujuh puluh persen) dari modal dasar, berdasarkan Pasal 33 ayat (1) UUPT 2007 dihubungkan dengan ketentuan Pasal 33 ayat (3) UUPT 2007 dan penjelasannya maka harus disetor penuh. Maksudnya adalah, misalkan modal ditempatkan 50\% (lima puluh persen) dari modal dasar berarti modal yang harus disetor penuh adalah 50\% (lima puluh persen), dan tidak dapat diangsur. Seperti yang dijelaskan pada Pasal 33 ayat (3) UUPT 2007 yang menegaskan bahwa tidak dimungkinkan penyetoran atas saham dengan cara mengangsur.

Seluruh saham yang telah dikeluarkan harus sudah disetor penuh pada saat pengesahan perseroan oleh menteri Kehakiman Republik Indonesia, dan dengan bukti penyetoran yang sah. Penundaan atau mengangsur, tidak mungkin dilakukan setelah pengesahan perseroan terbatas, karena pengeluaran saham lebih lanjut setiap kali harus disetor penuh. Demikian pula apabila ada pemegang saham yang mempunyai tagihan terhadap perseroan terbatas, maka tagihannya tidak boleh dipergunakan sebagai kompensasi kewajiban penyetoran atas harga sahamnya. Namun bentukbnetuk tagihan tertentu yang dapat dikompensasikan sebagai setoran atas saham, diatur lebih lanjut dalam Peraturan Pemerintah.

Mengenai penyetoran modal yang ditempatkan ini menurut Pasal 33 ayat (2) UUPT 2007, harus dibuktikan dengan tanda bukti penyetoran yang sah. Menurut penjelasaan pasal ini, bukti penyetoran yang sah, antara lain adalah bukti setoran pemegangsaham ke dalam rekening bank atas nama Peseroan Terbatas, data laporan keuangan yang telah diaudit oleh akuntan, atau neraca Perseroan Terbatas yang ditandatangani oleh Direksi dan Dewan Komisaris.

Dari uraian di atas dapat terlihat bahwa menurut ilmu hukum dikenal adanya 3 (tiga) macam penyertaan modal dalam sebuah Perseroan Terbatas. Modal dasar menunjukkan nilai saham maksimum yang dikeluarkan oleh sebuah Perseroan Terbatas. Modal dasar dapat dipahami sebagai jumlah seluruh modal yang boleh diterbitkan oleh perusahaan. Modal ditempatkan menyatakan kewajiban penyertaab modal yang disanggupi untuk diambil bagian oleh para pendiri perseroan terbatas maupun pemegang saham Perseroan Terbatas. Sedangkan modal disetor menunjukkan besarbya modal sesungguhnya yang telah dilaksanakan oleh para pendiri maupun pemegang saham dalam Perseroan 
Terbatas. $^{9}$

Penyetoran modal yang ditempatkan dan disetor penuh ini harus dibuktikan dengan bukti penyetoran yang sah. Bukti Penyetoran yang sah antara lain, bukti setoran pemegang saham ke dalam rekening bank atas nama Perseroan Terbatas, data dari laporan keuangan yang diaudit oleh akuntan, atau neraca Perseroan Terbatas yang ditandatangani oleh direksi dan dewan komisaris.

\section{Pengaturan Modal Perseroan Terbatas dalam Peraturan Pemerintah Nomor 29 Tahun 2016 tentang Perubahan Modal Dasar Perseroan Terbatas.}

Modal dasar dalam sebuah Perseroan Terbatas sebelumnya sudah mengalami berbagai dinamika perubahan ketentuan, dan pada tahun 1995 pertama kali ketentuan tentang Perseroan Terbatas tersebut diperkenalkan, dengan jumlah modal dasar pendirian Perseroan Terbatas pada saat itu paling sedikit adalah Rp. 20.000.000,- (dua puluh juta rupiah), kemudian pada tahun 2007 dirubah menjadi Rp. 50.000.000,- (lima puluh juta rupiah).

Dan kini seperti yang tercantum pada peraturan terbaru yaitu pada Pasal 1 ayat (3) Peraturan Pemerintah Nomor 29 Tahun 2016 tentang Perubahan Modal Dasar Perseroan Terbatas, modal dasar tersebut dikembalikan ke kesepakatan Para pendiri Perseroan Terbatas. Penghilangan jumlah modal dasar dilakukan agar para pengusaha leluasa menentukan besaran modal Perseroan Terbatas sesuai dengan kemampuan finansial mereka masingmasing. Sebenarnya Peraturan Pemerintah Nomor 29 Tahun 2016 tentang Perubahan Modal Dasar Perseroan Terbatas tetap meganut prinsip modal dasar paling sedikit Rp. 50.000.000,- (lima puluh juta rupiah). Tetapi jika salah satu atau seluruh pendiri hanya memiliki kekayaan bersih yang setara dengan kriteria Usaha Mikro, Kecil, dan Menengah (UMKM), maka modal dasarnya dapat ditentukan berdasarkan kesepatakan para pendiri perseroan. Namun kesepakatan itu harus dituangkan dalam akta pendirian perseroan terbatas.

Kriteria Usaha Mikro, Kecil, dan Menengah (UMKM) sesuai Undang-Undang Nomor 20 Tahun 2008 tentang Usaha Mikro, Kecil, dan Menengah (UMKM), adalah : ${ }^{10}$

a. Usaha Mikro, usaha produktif milik orang perorangan dan/atau badan usaha perorangan

\footnotetext{
9 Binoto Nadapdap, Hukum Perseroan Terbatas (Berdasrkan Undang-Undang No. 40 Tahun 2007), Jala Permata Aksara, Jakarta, 2016, h. 64.

${ }^{10}$ Lihat Undang-Undang Nomor 20 Tahun 2008 tentang Usaha Mikro, Kecil, dan Menengah.
}

yang memenuhi kriteria usaha mikro, sebagai berikut memiliki aset maksimal Rp. 50.000.000,(lima puluh juta rupiah), tidak termasuk tanah dan bangunan usaha, dan memiliki hasil penjualan tahunan paling banyak $\mathrm{Rp}$. 300.000 .000 ,- (tiga ratus juta rupiah);

b. Usaha Kecil, usaha ekonomi produktif yang berdiri sendiri, yang dilakukan oleh orang perorangan atau badan usaha yang bukan merupakan anak perusahaan atau cabang perusahaan yang dimiliki, dikuasai, atau menjadi bagian langsung maupun tidak langsung dari Usaha Menengah atau Usaha Besar yang memenuhi kriteria Usaha Kecil, sebagai berikut memiliki kekayaan bersih lebih dari Rp. 50.000.000,- (lima puluh juta rupiah) sampai paling banyak Rp. 500.000.000,(lima ratus juta rupiah) tidak termasuk tanah dan bangaunan tempat usaha, memiliki hasil penjualan lebih dari Rp. 300.000.000,- (tiga ratus juta rupiah) sampai dengan paling banyak Rp. 2.500.000.000,- (dua milyar lima ratus juta rupiah);

c. Usaha Menengah, usaha ekonomi produktif yang berdiri sendiri, yang dilakukan oleh orang perorangan atau badan usaha yang bukan merupakan anak perusahaan atau cabang perusahaan yang dimiliki, dikuasai, atau menjadi bagian langsung maupun tidak langsung dari Usaha Kecil atau Usaha Besar, dengan kekayaan bersih lebih dari Rp. 500.000.000,- (lima ratus juta rupiah) sampai paling banyak Rp. 10.000.000.000,- (sepuluh milyar rupiah) tidak termasuk tanah dan bangaunan tempat usaha, memiliki hasil penjualan lebih dari Rp. 2.500.000.000,- (dua milyar lima ratus juta rupiah) sampai dengan paling banyak Rp. 50.000.000.000,-- (lima puluh milyar rupiah).

Para pihak juga bisa menentukan modal dasar perseroan lebih besar dari yang ditentukan dalam UUPT. Norma semacam ini juga diakomodasi dalam Peraturan Pemerintah Nomor 29 Tahun 2016 tentang Perubahan Modal Dasar Perseroan Terbatas, seperti yang tercantum dalam Pasal 3 Peraturan Pemerintah Nomor 29 Tahun 2016 tentang Perubahan Modal Dasar Perseroan Terbatas "Undang-Undang yang mengatur kegiatan usaha tertentu dapat menentukan jumlah minimum modal Perseroan Terbatas yang lebih besar daripada ketentuan sebagaimana dimaksud dalan Pasal $1^{\prime \prime}$

Selain modal dasar, ada aspek lain yang diatur dalam Peraturan Pemerintah Nomor 29 Tahun 2016 tentang Perubahan Modal Dasar Perseroan Terbatas, yakni batas jangka waktu pengajuan bukti penyetoran modal Perseroan Terbatas ke Menteri Hukum dan Hak Asasi Manusia, yang sebelumnya 
baik di dalam UUPT maupun peraturan pelaksanaannya tidak ada ketentuan yang mengatur hingga spesifik itu.

Peraturan Pemerintah Nomor 29 Tahun 2016 tentang Perubahan Modal Dasar Perseroan Terbatas menegaskan bahwa bukti penyetoran modal wajib disampaikan secara elektronik kepada Menteri Hukum dan Hak Asasi Manusia paling lama 60 (enam puluh) hari sejak Akta Pendirian Perseroan Terbatas ditandatangani oleh para Pendiri Perseroan Terbatas.

Modal Perseroan Terbatas diatur pada Undang-Undang Nomor 40 Tahun 2007 tentang Perseroan Terbatas, dan juga diatur dalam Peraturan Pemerintah Nomor 29 Tahun 2016 tentang Perubahan Modal Dasar Perseroan Terbatas. Kedua peraturan tersebut ada sedikit perbedaan mengenai besaran Modal dasar Perseroan Terbatas, dan batas jangka waktu penyerahan bukti penyetoran modal Perseroan Terbatas, adapun perbedaan tersebut dapat kita lihat pada tabel dibawah ini :

\begin{tabular}{|c|c|c|}
\hline Peraturan & Modal Dasar & $\begin{array}{l}\text { Batas Jangka } \\
\text { Waktu }\end{array}$ \\
\hline $\begin{array}{l}\text { Undang- } \\
\text { Undang } \\
\text { Nomor } 1 \\
\text { Tahun } 1995 \\
\text { tentang } \\
\text { Perseroan } \\
\text { Terbatas }\end{array}$ & $\begin{array}{l}\text { a. Modal dasar : } \\
\text { Pasal } 25 \text { ayat } \\
\begin{array}{l}\text { (1), } \\
\text { dasar }\end{array} \\
\text { Perseroan } \\
\text { adalah paling } \\
\text { sedikit Rp } \\
20.000 .000,- \\
\text { (dua puluh } \\
\text { juta rupiah); } \\
\text { b. Modal } \\
\text { ditempatkan : } \\
\text { Pasal } 26 \text { ayat } \\
\text { (1), paling } \\
\text { sedikit } 25 \% \\
\text { (dua puluh } \\
\text { lima persen) } \\
\text { dari modal } \\
\text { dasar harus } \\
\text { telah } \\
\text { ditempatkan; } \\
\text { c. Modal disetor : } \\
\text { Pasal } 26 \text { ayat } \\
\text { (2), setiap } \\
\text { modal yang } \\
\text { ditempatkan, } \\
\text { paling sedikit } \\
50 \% \text { (lima } \\
\text { puluh persen) } \\
\text { sudah disetor } \\
\text { penuh. }\end{array}$ & $\begin{array}{l}\text { Tidak ada } \\
\text { ketentuan yang } \\
\text { mengatur } \\
\text { mengenai batas } \\
\text { jangka waktu } \\
\text { penyerahan } \\
\text { bukti setoran } \\
\text { modal } \\
\text { Perseroan } \\
\text { Terbatas. }\end{array}$ \\
\hline Undang- & a. Pasal 32 ayat & Tidak \\
\hline
\end{tabular}

\begin{tabular}{|c|c|c|}
\hline $\begin{array}{l}\text { Undang } \\
\text { Nomor } 40 \\
\text { Tahun } 2007 \\
\text { tentang } \\
\text { Perseroan } \\
\text { Terbatas }\end{array}$ & $\begin{array}{l}\text { (1), modal } \\
\text { dasar } \\
\text { Peseroan yang } \\
\text { dibenarkan } \\
\text { adalah paling } \\
\text { sedikit Rp } \\
50.000 .000,00 \\
\text { (lima puluh } \\
\text { juta rupiah). } \\
\text { b. Modal } \\
\text { ditempatkan } \\
\text { dan disetor : } \\
\text { pasal } 33 \text { ayat } \\
\text { (1), paling } \\
\text { sedikit 25 \% } \\
\text { (dua puluh } \\
\text { lima persen } \\
\text { dari modal } \\
\text { dasar harus } \\
\text { sudah } \\
\text { ditempatkan } \\
\text { dan disetor } \\
\text { penuh. }\end{array}$ & $\begin{array}{l}\text { ketentuan yang } \\
\text { mengatur } \\
\text { mengenai batas } \\
\text { jangka waktu } \\
\text { penyerahan } \\
\text { bukti setoran } \\
\text { modal } \\
\text { Perseroan } \\
\text { Terbatas. }\end{array}$ \\
\hline $\begin{array}{l}\text { Peraturan } \\
\text { Pemerintah } \\
\text { Nomor } 29 \\
\text { Tahun } 2016 \\
\text { tentang } \\
\text { Perubahan } \\
\text { Modal Dasar } \\
\text { Perseroan } \\
\text { Terbatas }\end{array}$ & $\begin{array}{l}\text { Pasal } 1 \text { ayat (3), } \\
\text { besaran modal } \\
\text { dasar Perseroan } \\
\text { Terbatas } \\
\text { ditentukan } \\
\text { berdasarkan } \\
\text { kesepakatan para } \\
\text { pendiri Perseroan } \\
\text { Terbatas. }\end{array}$ & $\begin{array}{l}\text { Pasal } 2 \text { ayat (2), } \\
\text { bukti setoran } \\
\text { yang sah wajib } \\
\text { disampaikan } \\
\text { secara } \\
\text { elektronik } \\
\text { kepada menteri } \\
\text { yang jerang } \\
\text { bersangkutan } \\
\text { dalam jangka } \\
\text { waktu paling } \\
\text { lama } 60 \text { (enam } \\
\text { puluh) hari } \\
\text { sejak tanggal } \\
\text { akta pendirian } \\
\text { Perseroan } \\
\text { Terbatas } \\
\text { ditandatangani }\end{array}$ \\
\hline
\end{tabular}

Alasan Mengenai Pembuatan dan Perubahan Ketentuan Modal Perseroan Terbatas.

Alasan pemerintah menyerahkan penentuan besaran modal dasar Perseroan Terbatas kepada para pendiri Pesrseroan Terbatas dilatarbelakangi kondisi yang dialami oleh dunia usaha, khususnya bagi pengusaha pemula untuk mendirikan suatu Perseroan Terbatas. Penyesuain tersebut dimaksudkan untuk memberikan kemudahan berusaha, dan dapat menjamin ketertiban dunia usaha dalam investasi dengan mengubah besaran modal dasar yang dirasakan masih sangat memberatkan para pengusaha pemula. Seperti yang 
tertera dalam Penjelasan Umum Peraturan Pemerintah Nomor 29 Tahun 2016 tentang Perubahan Modal Dasar Perseroan Terbatas, yaitu "Peraturan ini dibentuk dalam rangka memberikan kepastian hukum bagi pelaku pembangunan ekonomi nasional khususnya dalam memulai usaha". Perubahan tersebut merupakan salah satu cara untuk meningkatkan kemudahan berusaha bagi usaha mikro, kecil, dan menengah (UMKM) dan juga untuk melaksanakan ketentuan Pasal 32 ayat (3) UUPT.

Selain alasan tersebut, hal lainnya yang menjadi pertimbangan bagi pemerintah yang akhirnya mengesampingkan UUPT berkenaan dengan upaya penghormatan terhadap asas kebebasan berkontrak dengan memberikan kebebasan yang seluas-luasnya kepada masyarakat untuk mengadakan perjanjian dalam mendirikan Perseroan Terbatas berdasarkan ketentuan yang tercantum dalam hukum perdata. Ketentuan ini juga untuk meningkatkan investasi yang pada gilirannya akan mendorong pertumbuhan usaha mikro, kecil, dan menengah (UMKM) menjadi lebih baik lagi. Keringanan ini tidak hanya terbaats pada pembentukan Perseroan Terbatas dengan kriteria Usaha Mikro, Kecil, dan Menengah (UMKM), tetapi juga berlaku secara umum untuk berbagai skala bisnis perseroan.

Selama ini Usaha Mikro, Kecil, dan Menengah (UMKM) lebih memilih untuk mendirikan CV (Persekutuan Komanditer) dibandingkan dengan Perseroan Terbatas dengan alasan modal yang paspasan, maka dengan diundangkannya Peraturan Pemerintah Nomor 29 Tahun 2016 tentang Perubahan Modal Dasar Perseroan Terbatas ini bisa menjadi opsi yang lebih baik.

\section{PENUTUP}

\section{Kesimpulan}

Dari uraian sebelumnya dilihat, adanya pembatasan modal minimal dalam Perseroan Terbatas, alasan pemerintah memberikan pembatasan tersebut adalah untuk mempermudah pertanggungjawaban para pemegang saham dalam Perseroan Terbatas tersebut. Seperti kita ketahui secara garis besar badan usaha terdiri dari 2 (dua) macam, yaitu badan usaha yang bukan (tidak) berbadan hukum dan badan usaha yang berbadan hukum. badan usaha yang termasuk tidak berbadan hukum adalah perserkutuan perdata, perseroan komanditer, persekutuan dengan firma, dan perusahaan dagang. Sedangkan yang merupakan badan usaha yang berbadan hukum adalah peresroan terbatas.
Perbedaan yang mendasar di antara kedua jenis badan usaha yang bukan berbadan hukum dan yang berbadan hukum adalah terletak pada tanggung jawab pemilik perseroan terbatas (pemegang saham). Bagi badan usaha yang berbadan hukum, tanggung jawab pemegang saham adalah terbatas pada sebesar modal yang disanggupi. Sedangkan yang bukan berbadan hukum tanggung jawab pemegang saham adalah tidak terbatas pada jumlah modal yang disanggupi, akan tetapi bisa juga sampai pada pertanggungjawaban pribadi. ${ }^{11}$ Karena adanya pembatasan tanggung jawab ini, menjadikan perseroan terbatas menjadi salah satu pilihan bentuk usaha yang banyak diminati dalam menjalankan roda bisnis. Selain itu, pembatasan modal dalam Perseroan Terbatas juga berfungsi sebagai pembeda Perseroan Terbatas dengan badan usaha yang tidak berbadan hukum.

Kemudian, alasan pemerintah melakukan pengubahan terkait modal dalam Perseroan Terbatas adalah penyesuain tersebut dimaksudkan untuk memberikan kemudahan berusaha, dan dapat menjamin ketertiban dunia usaha dalam investasi dengan mengubah besaran modal dasar yang dirasakan masih sangat memberatkan para pengusaha pemula. Seperti yang tertera dalam Penjelasan Umum Peraturan Pemerintah Nomor 29 Tahun 2016 tentang Perubahan Modal Dasar Perseroan Terbatas, yaitu "Peraturan ini dibentuk dalam rangka memberikan kepastian hukum bagi pelaku pembangunan ekonomi nasional khususnya dalam memulai usaha". Perubahan tersebut merupakan salah satu cara untuk meningkatkan kemudahan berusaha bagi usaha mikro, kecil, dan menengah (UMKM) dan juga untuk melaksanakan ketentuan Pasal 32 ayat (3) UUPT.

Selain alasan tersebut, hal lainnya yang menjadi pertimbangan bagi pemerintah yang akhirnya mengesampingkan UUPT 2007 berkenaan dengan upaya penghormatan terhadap asas kebebasan berkontrak dengan memberikan kebebasan yang seluas-luasnya kepada masyarakat untuk mengadakan perjanjian dalam mendirikan Perseroan Terbatas berdasarkan ketentuan yang tercantum dalam hukum perdata. Ketentuan ini juga untuk meningkatkan investasi yang pada gilirannya akan mendorong pertumbuhan usaha mikro, kecil, dan menengah (UMKM) menjadi lebih baik lagi. Keringanan ini tidak hanya terbaats pada pembentukan Perseroan Terbatas dengan kriteria Usaha Mikro, Kecil, dan Menengah (UMKM), tetapi juga berlaku secara umum untuk berbagai skala

\footnotetext{
11 Sentosa Sembiring, Hukum Perusahaan tentang Perseroan Terbatas, Bandung, Nuansa Aulia, 2007, h. 13.
} 
bisnis perseroan. Selama ini Usaha Mikro, Kecil, dan Menengah (UMKM) lebih memilih untuk mendirikan CV (Persekutuan Komanditer) dibandingkan dengan Perseroan Terbatas dengan alasan modal yang paspasan, maka dengan diundangkannya Peraturan Pemerintah Nomor 29 Tahun 2016 tentang Perubahan Modal Dasar Perseroan Terbatas ini bisa menjadi opsi yang lebih baik untuk Perseroan Terbatas.

\section{Saran}

Perlu adanya sosialisasi yang baik kepada seluruh masyarakat yang berhubungan perseroan terbatas, terkait peraturan pemerintah yang terbaru ini, agar seluruh masyarakat mengetahui peraturan tersebut dan apa yang dicita-citakan oleh pemerintah untuk memberikan kemudahan berusaha dapat terlaksana dengan baik. Selain itu, perlu adanya pengaturan lebih lanjut mengenai pertanggungjawaban dari para pendiri Perseroan Terbatas, agar pertanggungjawaban tersebut tidak melebar hingga ke harta pribadi pendiri Perseroan Terbatas itu sendiri.

\section{DAFTAR PUSTAKA}

Agus Budiarto. 2009. Kedudukan Hukum dan Tanggungjawab Pendiri Perseroan Terbatas. Bogor : Ghalia Indonesia.
Binoto Nadapdap. 2016. Hukum Perseroan Terbatas (Berdasarkan Undang-Undang No. 40 Tahun 2007). Jakarta : Jala Permata Aksara.

Jamin Ginting. 2007. Hukum Perseroan Terbatas (Undang-undang Nomor 40 Tahun 2007). Bandung : Citra Aditya Bakti.

M. Yahya Harahap. 2011. Hukum Perseroan Terbatas. Jakarta : Sinar Grafika.

Ridwan Khairandy. 2009. Perseroan Terbatas Doktrin, Peraturan Perundang-undangan, dan Yurispudensi, Yogyakarta : Total Media.

Walter Woon. 1998. Company Law. Singapore : Longman Singapore Publisher Pte Ltd.

Undang-Undang Nomor 1 Tahun 1995 tentang Perseroan Terbatas.

Undang-Undang Nomor 40 tahun 2007 tentang Perseroan Terbatas.

Undang-Undang Nomor 20 Tahun 2008 tentang Usaha Mikro, Kecil, dan Menengah.

Peraturan Pemerintah Nomor 29 Tahun 2016 tentang Perubahan Modal Dasar Perseroan Terbatas. 